\title{
Different Drummers
}




\section{MUSIC OF THE AFRICAN DIASPORA}

Guthrie P. Ramsey, Jr., Editor

Samuel A. Floyd, Jr., Editor Emeritus

1. California Soul: Music of African Americans in the West, edited by Jacqueline Cogdell DjeDje and Eddie S. Meadows

2. William Grant Still: A Study in Contradictions, by Catherine Parsons Smith

3. Jazz on the Road: Don Albert's Musical Life, by Christopher Wilkinson

4. Harlem in Montmartre: A Paris Jazz Story between the Great Wars, by William A. Shack

5. Dead Man Blues: Jelly Roll Morton Way Out West, by Phil Pastras

6. What Is This Thing Called Jazz?: African American Musicians as Artists, Critics, and Activists, by Eric Porter

7. Race Music: Black Cultures from Bebop to Hip-Hop, by Guthrie P. Ramsey, Jr.

8. Lining Out the Word: Dr. Watts Hymn Singing in the Music of Black Americans, by William T. Dargan

9. Music and Revolution: Cultural Change in Socialist Cuba, by Robin D. Moore

10. From Afro-Cuban Rhythms to Latin Jazz, by Raul A. Fernandez

11. "Mek Some Noise": Gospel Music and the Ethics of Style in Trinidad, by Timothy Rommen

12. The Memoirs of Alton Augustus Adams, Sr.: First Black Bandmaster of the United States Navy, edited with an introduction by Mark Clague, with a foreword by Samuel Floyd, Jr.

13. Digging: The Afro-American Soul of American Classical Music, by Amiri Baraka 14. Different Drummers: Rhythm and Race in the Americas, by Martin Munro 


\section{Different Drummers}

Rhythm and Race in the Americas

Martin Munro

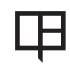

UNIVERSITY OF CALIFORNIA PRESS

Berkeley Los Angeles London 
University of California Press, one of the most distinguished university presses in the United States, enriches lives around the world by advancing scholarship in the humanities, social sciences, and natural sciences. Its activities are supported by the UC Press Foundation and by philanthropic contributions from individuals and institutions. For more information, visit www.ucpress.edu.

University of California Press

Berkeley and Los Angeles, California

University of California Press, Ltd.

London, England

(C) 2010 by The Regents of the University of California

Library of Congress Cataloging-in-Publication Data

Munro, Martin.

Different drummers : rhythm and race in the Americas / Martin Munro.

p. $\quad \mathrm{cm} .-$ (Music of the African diaspora ; 14)

Includes bibliographical references and index.

ISBN 978-0-520-26282-9 (cloth : alk. paper)

ISBN 978-0-520-26283-6 (pbk : alk. paper)

1. Blacks-Caribbean Area-Music-History and criticism.

2. African Americans-Music-History and criticism. 3. Brown, James, 1933-2006-Criticism and interpretation. I. Title.

ML3550.M86 2010

$780.89 ' 960729-\mathrm{dc} 22$

2010005646

Manufactured in the United States of America

$\begin{array}{llllllllll}19 & 18 & 17 & 16 & 15 & 14 & 13 & 12 & 11 & 10\end{array}$

$\begin{array}{llllllllll}10 & 9 & 8 & 7 & 6 & 5 & 4 & 3 & 2 & 1\end{array}$

This book is printed on Cascades Enviro 100, a 100\% postconsumer waste, recycled, de-inked fiber. FSC recycled certified and processed chlorine free. It is acid free, Ecologo certified, and manufactured by BioGas energy. 
For Cheralyn 
This page intentionally left blank 